\title{
Mene Tekel 2018
}

Ve dnech 24. února až 4. března 2018 se v Praze a Brně uskutečnil XII. ročník mezinárodního festivalu proti totalitě, zlu a násilí, pro pamět' národa Mene Tekel, tentokrát na téma Odkaz osobností československé armády. Z bohatého a pestrého programu festivalu, který se stal neodmyslitelnou součástí kulturního dění v českých zemích, vyjměme jeho závěrečnou část, na níž se aktivně podíleli především členové akademické obce Právnické fakulty Univerzity Karlovy: rekonstrukci politického procesu Kučera a spol.

Studenti pražských práv již podesáté pod odborným vedením garanta volitelného předmětu Vědecký seminár̆ Rekonstrukce politického procesu z 50. let a děkana Právnické fakulty Univerzity Karlovy prof. JUDr. Jana Kuklíka, DrSc., doktorandů působících na Katedře právních dějin a ředitele festivalu Mene Tekel Mgr. Jana Řeřichy připravili divadelní rekonstrukci jednoho z př́ípadů zvůle komunistického režimu. V souladu s tématem letošního ročníku festivalu byl v úzké spolupráci s PhDr. Alenou Šimánkovou ze 4. oddělení Národní archivu vybrán proces Kučera a spol., jehož obětí se kromě na smrt odsouzeného vojáka Josefa Kučery stal i významný představitel druhého a třetího odboje Tomáš Sedláček.

Přípravné práce započaly jako obvykle již bezprostředně po ukončení předcházejícího, XI. ročníku festivalu Mene Tekel. V letních měsících roku 2017 v Národním archivu Mgr. Jan Řeřicha ve spolupráci s historiky a pamětníky - členy Konfederace politických vězňů České republiky - prostudoval dochované archiválie, aby se s jejich výběrem mohli studenti seznámit hned po zahájení výuky v akademickém roce 2017/2018. V řríjnu a listopadu spolu s vedoucími vědeckého semináře, doktorandy na Katedře právních dějin, JUDr. Danielou Němečkovou a Mgr. Lukášem Blažkem, a studentkou magisterského studia Terezou Blažkovou, začala důkladná teoretická př́iprava studentů. Po úvodu do problematiky fungování komunistické justice následovala intenzivní práce s dobovými právními předpisy, zejména se zákonem o ochraně lidově demokratické republiky z roku 1948, trestním zákonem z roku 1950 a procesněprávními předpisy. V závěru první části odborné př́pravy si studenti mohli ověřit nabyté znalosti a dovednosti prostřednictvím cvičné subsumpce několika skutků pod př́slušné skutkové podstaty uvedené v zákoně na ochranu lidově demokratické republiky.

Druhá fáze vědeckého semináře byla v gesci režiséra Mgr. Jana Řeřichy, ředitele festivalu Mene Tekel. Po rozdělení „divadelních rolí“ - postav procesu - následovala práce s dochovanými archiváliemi, na jejichž základě byl zrekonstruován průběh jednotlivých fází trestního řízení. Studenti si při práci s protokoly z hlavního líčení mimo jiné uvědomo- 
vali, jak náročné je rekonstruovat jednotlivé výslechy, zvláště když k tomuto případu nebyly k dispozici žádné zvukové či zvukově obrazové záznamy. Jak nesnadné je z protokolů vyčíst výpovědi obviněných, zahalené do zideologizovaného podání vyslýchajícího soudce zaznamenaného soudním zapisovatelem. Významnou pomůckou ale byly vzpomínky arm. gen. Ing. Tomáše Sedláčka, zachycené v knize PhDr. Jiřího Plachého Vydržet! (druhé, doplněné vydání vyšlo v roce 2015). Na základě rekonstruovaných částí trestního řízení nakonec studenti se scénáristou a režisérem Mgr. Janem Řeřichou přistoupili k sestavení první verze scénáře.

Jednotlivé části představení se následně „dopilovaly“ v průběhu ledna a února, kdy se konaly individuální zkoušky protagonistů v prostorách cvičné soudní síně Právnické fakulty Univerzity Karlovy. Po ukončení těchto zkoušek se již s definitivní verzí scénáře uskutečnily tři generální zkoušky v Collegium Maximum fakulty.

Pomyslný „den D“ nastal v sobotu 3. března 2018. Na půdě porotní síně Vrchního soudu v Praze na Pankráci studenti pod vedením Mgr. Jana Řeřichy a jeho spolupracovníků, historiků vězeňství PhDr. Aleše Kýra a Aleny Kafkové, absolvovali poslední zkoušku představení. Studentské divadlo faktu začalo ve 14 hodin a trvalo asi 90 minut. Po představení následovala diskuse, moderovaná prof. JUDr. Janem Kuklíkem, DrSc., a pietní zastavení u pamětní desky obětem nacistické a komunistické totality ve vestibulu Vazební věznice Praha-Pankrác. Pro ty, kteří neměli možnost shlédnout představení naživo, je k dispozici záznam na iVysílání České televize.

Závěrem nutno dodat, že vědecká př́íprava divadelní rekonstrukce ani divadlo samotné nejsou bezúčelnou hrou studentů a jejich učitelů. V průběhu teoretické přípravy se mají studenti možnost seznámit nejenom s původními soudními a vězeňskými spisy a jinými dochovanými archivními materiály a osvojit si tak základní postupy právněhistorické vědy, ale pod odborným vedením mohou nazřít přímo pod pokličku totalitní justice. Ve vyučování totiž nejde pouze o znalosti a dovednosti, ale také o postoje studentů. Student práv, který stojí na prahu své budoucí odborné dráhy, se má již v této chvíli možnost poučit, jak málo stačilo jeho předchůdcům $\mathrm{k}$ tomu, aby podlehli vábení moci a zaprodali se službám zla.

doi: 10.14712/2464689X.2018.33

Adam Csukás 